\title{
Enzymatic synthesis of perfluoroalkylated DNA
}

\author{
Bastian Holzberger, Andreas Marx* \\ Department of Chemistry and Konstanz Research School Chemical Biology, University of Konstanz, Universitätsstrasse 10, P.O. Box 726, 78457 Konstanz, Germany
}

\section{A R T I C L E I N F O}

Keywords:

DNA

Modified nucleotide

DNA polymerase

Fluor

SELEX

\begin{abstract}
A B S T R A C T
Thymidine analogues 5 trifluoromethyl , 5 pentafluoroethyl and 5 (heptafluoro $n$ propyl) $2^{\prime}$ deoxyuri dines were synthesised and converted into the corresponding $5^{\prime}$ triphosphates 1a c. Performing DNA polymerase catalyzed primer extension reactions these modified nucleotides were incorporated into DNA to create perfluoroalkylated nucleic acids. Although single modified nucleotides were enzymatically incorporated and further elongated quite similar to the natural TTP, the enzymatic synthesis of multi modified nucleic acids was initial only feasible with modifications at every fourth base. Nevertheless, as the effects of the modified dUTPs on DNA polymerases varied significantly with the used enzyme, Therminator DNA polymerase was proficient in incorporating 11 adjacent 5 trifluoromethyl 2' deoxyur idine moieties.
\end{abstract}

\section{Introduction}

Aside from being the fundamental genetic material for the stor age and transfer of information, DNA has recently gained signifi cant attention as building block in nanotechnology. ${ }^{1}$ The introduction of chemically modified DNA building blocks may offer the possibility to modify the physical and geometrical properties of DNA. The generation of new DNA based materials through enzy matic synthesis is particularly promising, since this approach has the potential to introduce non nucleic acid like functionalities through usage of modified building blocks and their incorporation into long DNA stretches by DNA polymerases. ${ }^{2}$ Although this ap proach has only sparsely been exploited so far, ${ }^{2}$ several different modifications were successfully incorporated to create highly functionalized DNA double strands. ${ }^{3}$ Aside from amino acid groups, aromatic, basic, acidic and lipophilic modifications, functionalized dNTPs were also used to introduce $\mathrm{Ru}(\mathrm{II})$ and $\mathrm{Os}(\mathrm{II})$ complexes into DNA double strands. ${ }^{4}$ Furthermore, alkyne and azido labelled oli gonucleotides offer the possibility to post synthetically modify DNA oligonucleotides by 'Click' chemistry or Staudinger ligation. ${ }^{5}$ Recently, we used DNA polymerases for the construction of DNA based networks ${ }^{6}$ and site specific multi spinlabelled DNA. ${ }^{7}$ In addition, modified DNA has been employed in the generation of aptamers and catalytically active DNA. ${ }^{8,9}$ These entities were ob tained by SELEX that requires that the respective modified nucleo tides are substrates for DNA polymerases.

Due to its small van der Waals radius and the stability of the highly polarized bond formed with carbon, fluorine is used in var

* Corresponding author. Tel.: +49 753188 5139; fax: +49 7531885140 . E-mail address: Andreas.Marx@uni-konstanz.de (A. Marx). ious approaches in bioorganic and medicinal chemistry. ${ }^{10}$ Fluorine is highly electronegative and shows unique nuclear magnetic res onance (NMR) spectroscopic parameters. The substitution of hydrogen by fluorine leads to significant electronic effects and can modify properties of a molecule like $\mathrm{p} K_{\mathrm{a}}$ values, dipole mo ments or chemical reactivities and stabilities of adjacent functional groups. ${ }^{11}$ Although fluorine is used as an isosteric replacement for hydrogen, the introduction of fluorine into a molecule leads to ste ric changes as well. This is caused by different van der Waals radii of fluorine (1.47 $\AA$ ) and hydrogen $(1.2 \AA)$ and different bond lengths of $\mathrm{C} H(1.09 \AA)$ and $\mathrm{C} F(1.35 \AA) .{ }^{11}$ However, fluorinated substrate analogues are often used as mechanistic probes to study enzyme catalysis. ${ }^{10 \mathrm{c}}$ Furthermore, fluorine is applied in monitoring functional important transitions in biological systems via ${ }^{19} \mathrm{~F}$ NMR spectroscopic methods. ${ }^{12}$

The fluorinated thymidine analogue 5 trifluoromethyl $2^{\prime}$ deoxy uridine $\left(\mathrm{CF}_{3} \mathrm{dU}\right)$ has been shown to form regular base pairs with adenosine. By replacing an internal thymidine residue in DNA oli gonucleotides with $\mathrm{CF}_{3} \mathrm{dU}$ DNA double helices are formed that still adopt the $\mathrm{B}$ form conformation. ${ }^{13}$ Thereby, the substitution of a thymidine residue by $\mathrm{CF}_{3} \mathrm{dU}$ causes a slight decrease in DNA du plex stability. ${ }^{14}$ Apart from chemical methods to introduce modi fied nucleosides into DNA oligonucleotides by using suitable building blocks in automated DNA synthesis, enzymatic incorpora tion of modified nucleoside $5^{\prime}$ triphosphates by DNA polymerases allows the synthesis of long multi modified DNA oligonucleotides. ${ }^{2}$ Albeit it was claimed that $\mathrm{CF}_{3} \mathrm{dU} 5^{\prime}$ triphosphate is a substrate for DNA polymerases in vitro, ${ }^{15}$ experimental results have not been documented. In addition, the effect of extended C5 perfluoro mod ifications in $2^{\prime} \mathrm{dU} 5^{\prime}$ triphosphates has not been explored so far. Here we present the introduction of 5 trifluoromethyl, 5 penta 
fluoroethyl and 5 (heptafluoro $n$ propyl) dU residues into DNA by exploiting DNA polymerase catalyzed template directed reac tions and modified triphosphates 1a c.

\section{Results and discussion}

First, we synthesized the 5 perfluoroalkyl $2^{\prime}$ deoxyuridine $5^{\prime}$ triphosphates 1a c (Scheme 1).

The synthesis started with 2a c that were synthesized follow ing published procedures..$^{16} 2 \mathrm{a}$ was deacetylated according to the reported procedure by using a $7 \mathrm{M}$ ammonia solution of metha nol. ${ }^{16}$ However, this method gave unsatisfactory results for $\mathbf{2 b}$ and $\mathbf{c}$ due to the formation of side products. Due to the known reactivity and instability of the trifluoromethyl group of 5 trifluo romethyluracil towards nucleophiles and under basic conditions, ${ }^{17}$ we applied a different method for deacetylation of $\mathbf{2 b}$ and $\mathbf{2 c}$. By use of toluene 4 sulfonic acid monohydrate in dichloromethane and methanol, we were able to synthesize $3 \mathbf{b}$ and $3 \mathbf{c}$. Compounds 3a c were subsequently transformed to the nucleoside $5^{\prime}$ triphos phates 1a c. ${ }^{18}$

Next, we explored the action of 1a $\mathbf{c}$ on DNA polymerases and investigated the ability of the Klenow fragment of Escherichia coli DNA polymerase I $\left(3^{\prime} \rightarrow 5^{\prime}\right.$ exonuclease deficient variant, $\operatorname{KF}($ exo $\left.)\right)$ and the Klenow fragment of Thermus aquaticus DNA polymerase (KlenTaq) to accept 1a $\mathbf{c}$ in primer extension experiments. There fore, we used a ${ }^{32} \mathrm{P} 5^{\prime}$ end labelled primer ( $\left.23 \mathrm{nt}\right) /$ template ( $\left.35 \mathrm{nt}\right)$ complex with an adenosine residue at position 27 of the template to direct the usage of TTP and the thymidine analogues 1a c, respectively, after incorporation of three natural nucleotides (Fig. 1a).

Subsequently all reactions were analyzed by denaturing poly acrylamide gel electrophoresis (PAGE) and phosphor imaging. In the presence of dGTP, dCTP and AATP and the absence of any TTP analogue, primer elongation was paused at position 27 when using $\operatorname{KF}($ exo ) or KlenTaq (Fig. 1b and c, TTP). When all four natural dNTPs were present, formation of full length products was moni tored with both enzymes (Fig. 1b and $c,+$ TTP). Substitution of TTP by 1a $\mathbf{c}$ led with both enzymes to full length products as well (Fig. $1 \mathrm{~b}$ and $\mathrm{c}, \mathrm{CF}_{3} \mathrm{dUTP}, \mathrm{C}_{2} \mathrm{~F}_{5} \mathrm{dUTP}, \mathrm{C}_{3} \mathrm{~F}_{7} \mathrm{dUTP}$ ). The incorporation of an additional nucleotide in a non templated manner led to the $36 \mathrm{nt}$ long products. This has been observed before using $3^{\prime} \rightarrow 5^{\prime}$ exonuclease deficient DNA polymerases. ${ }^{19}$

To get first insights into the efficiency and selectivity of the enzymatic incorporation step in particular, we examined the acceptance of 1a c by $\mathrm{KF}($ exo $)$ catalysis performing single incor poration experiments in the presence of different concentrations of TTP and 1a c, respectively. Thus, we used four different ${ }^{32} \mathrm{P} 5^{\prime}$ end labelled primer ( $24 \mathrm{nt}) /$ template ( $36 \mathrm{nt}$ ) complexes with all four natural nucleotide residues at the first position after the $3^{\prime}$ end of the primer (Fig. 2a). Doing so, we observed two bands after PAGE analysis, the given $24 \mathrm{nt}$ long primer and the elongated one

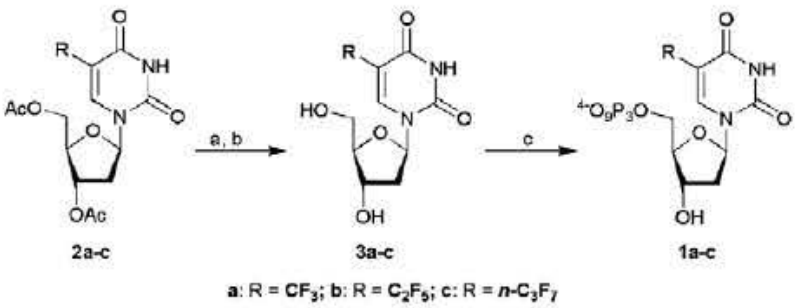

Scheme 1. Synthesis of 5-perfluoroalkylated dUTP analogues 1a-c. Reagents and yields: (a) $\mathrm{NH}_{3} / \mathrm{MeOH}$ (7 M), 76\%(3a); (b) p- TsOH. $\mathrm{H}_{2} \mathrm{O}, \mathrm{DCM} / \mathrm{MeOH}$ (9:1), 74\% (3b), 66\% (3c); (c) 1,8-bis-(dimethylamino)-naphthalene, $\mathrm{POCl}_{3},\left(\mathrm{CH}_{3} \mathrm{O}\right)_{3} \mathrm{PO}$ then (n$\left.\mathrm{Bu}_{3} \mathrm{NH}\right)_{2} \mathrm{H}_{2} \mathrm{P}_{2} \mathrm{O}_{7}, \mathrm{Et}_{3} \mathrm{~N}, 8 \%$ (1a), 10\%(1b), 16\%(1c). (a) $\begin{array}{ll}\text { Primer (23 nt): } & \text { 5'--TC } \\ \text { Template (35 nt): } & \text { 3'--AGG GCA CGG TCG CG }\end{array}$ (b) 35

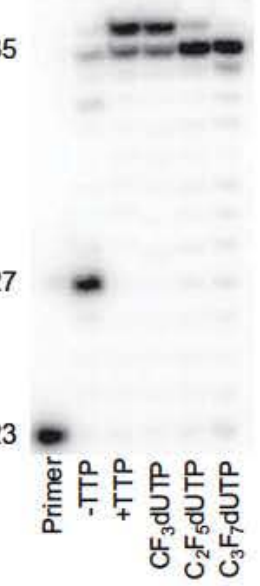

(c)

35

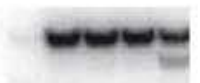

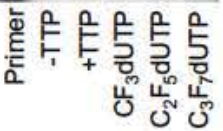

Figure 1. Primer extension studies: acceptance of 1a-c by KF(exo-) (b) and KlenTaq (c). (a) Partial primer template sequences employed. (b) and (c) Primer: primer only: -TTP: primer extension in the presence of dATP, dGTP and dCTP; +TTP: as -TTP but in the presence of TTP; $\mathrm{CF}_{3} \mathrm{dUTP}$ : as -TTP but in the presence of $1 \mathrm{a}$; $\mathrm{C}_{2} \mathrm{~F}_{5}$ dUTP: as -TTP but in the presence of $1 \mathrm{~b} ; \mathrm{C}_{3} \mathrm{~F}_{7} \mathrm{dUTP}$ : as -TTP but in the presence of $1 \mathrm{c}$.

(25 nt) in most cases. In general, incorporation of the modified thymidines was comparable to that of the natural counterpart (Fig. 2). Especially 1a led to similar product yields opposite the four natural nucleotide residues (quantified by phosphor imaging).

(a) $\quad$ 5rimer:-ACA $2^{T^{*} \mathrm{TP}}$

Template: 3 '--TGT NCT GTC TGC GTG

(b) $\mathrm{N}=\mathrm{A}$

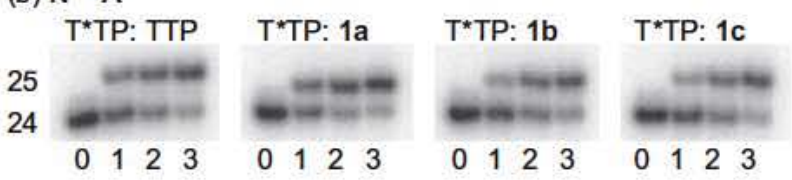

(c) $\mathbf{N}=\mathbf{G}$

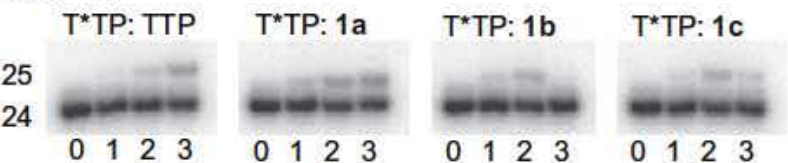

(d) $\mathrm{N}=\mathrm{C}$

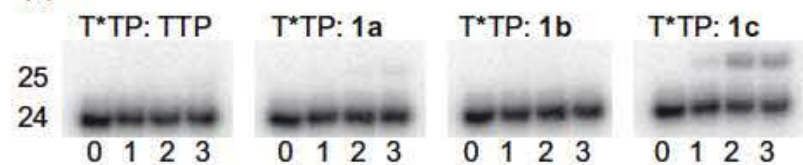

(e) $\mathrm{N}=\mathrm{T}$

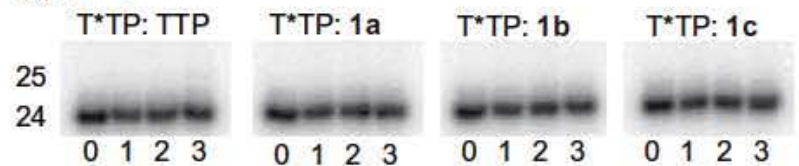

Figure 2. Single incorporation employing TTP and 1a-c by KF(exo-) with differing nucleotide concentrations. (a) Partial primer template sequences employed. (b) Incorporation opposite A (matçhed case, $t=5 \mathrm{~min}$ ); lanes 0 : primer only, lanes 1: $1 \mu \mathrm{M}$ T TP, lanes 2: $10 \mu \mathrm{M}$ T TP, lanes 3: $100 \mu \mathrm{M}$ T TP. (c-e) Incorporation opposite $\mathrm{G} / \mathrm{C} / \mathrm{T}$ (mismatched cases, $t=30 \mathrm{~min}$ ); lanes 0 : primer only, lanes $1: 10 \mu \mathrm{M}$ $\mathrm{T}$ TP, lanes 2: $50 \mu \mathrm{M} T$ TP, lanes 3: $200 \mu \mathrm{M} \mathrm{T}$ TP. 
Higher concentrations of $\mathbf{1 b}$ and $\mathbf{1 c}$ inhibited the incorporation opposite the guanosine residue (Fig. 2c, right two panels, lanes 3 ). Even more unexpected was that TTP, 1a and 1b were not, but 1c was used as substrate for incorporation opposite the non canonical cytosine residue in the template (Fig. 2d).

Next, we investigated the multiple incorporations of the modi fied nucleotides into DNA by using different templates that call for usage of TTP and 1a c, respectively, at every fourth, every second or every singular nucleotide position. Figure 3 shows the results obtained in multiple incorporation experiments by using $\mathrm{KF}($ exo ). Using the template with an adenosine residue at every fourth posi tion, we obtained full length products when natural TTP was substituted by 1a c (Fig. $3 a, C_{3} d U T P, C_{2} F_{5} d U T P, C_{3} F_{7} d U T P$ ). The acceptance of $\mathbf{1 a} \mathbf{c}$ at every second position led only in the case of $\mathbf{1 a}$ to the full length product (Fig. $3 \mathrm{~b}, \mathrm{CF}_{3} \mathrm{dUTP}$ ). The template with an adenosine residue at every position could not be extended to full length with any of the TTP analogues (Fig. 3c, $\mathrm{CF}_{3} \mathrm{dUTP}$, $\mathrm{C}_{2} \mathrm{~F}_{5} \mathrm{dUTP}, \mathrm{C}_{3} \mathrm{~F}_{7} \mathrm{dUTP}$ ). Although the modified nucleotides were incorporated opposite the adenosine residue in comparable yields to the natural counterpart (Fig. 2b), the multiple incorporation of additional nucleotide analogues was inhibited. With employed conditions we obtained reaction products that were only elongated by one or two $(\mathbf{1 b}, \mathbf{1 c})$ or four incorporated thymidine analogues in the case of 1a (Fig. 3c, $\mathrm{CF}_{3}$ dUTP, $\mathrm{C}_{2} \mathrm{~F}_{5} \mathrm{dUTP}, \mathrm{C}_{3} \mathrm{~F}_{7} \mathrm{dUTP}$ ).

However, we found that the effects of 1a $\mathbf{c}$ on DNA polymer ases significantly vary with the used enzyme. It was found that Therminator DNA polymerase (A485L mutant of Thermococcus spe cies $9^{\circ} \mathrm{N}$ DNA polymerase) is most proficient in processing multiple incorporations of these modified nucleotides. In order to form one entire DNA helix turn of 5 perfluoroalkyl 2 ' deoxyuridines, we used a template with eleven adjacent adenosine residues (Fig. 4a).

Due to the known decrease in stability of DNA helices with internal $\mathrm{CF}_{3} \mathrm{dU}$ residues, ${ }^{14}$ we examined the multiple incorporation experiments at temperatures between 37 and $70^{\circ} \mathrm{C}$. Interestingly, Therminator DNA polymerase is proficient in incorporating eleven adjacent $\mathrm{CF}_{3} \mathrm{dU}$ nucleotides at about 40 to $60^{\circ} \mathrm{C}$ (Fig. 4b, left panel, lanes 3 8). In case of $\mathbf{1 b}$ and $\mathbf{1 c}$ Therminator DNA polymerase
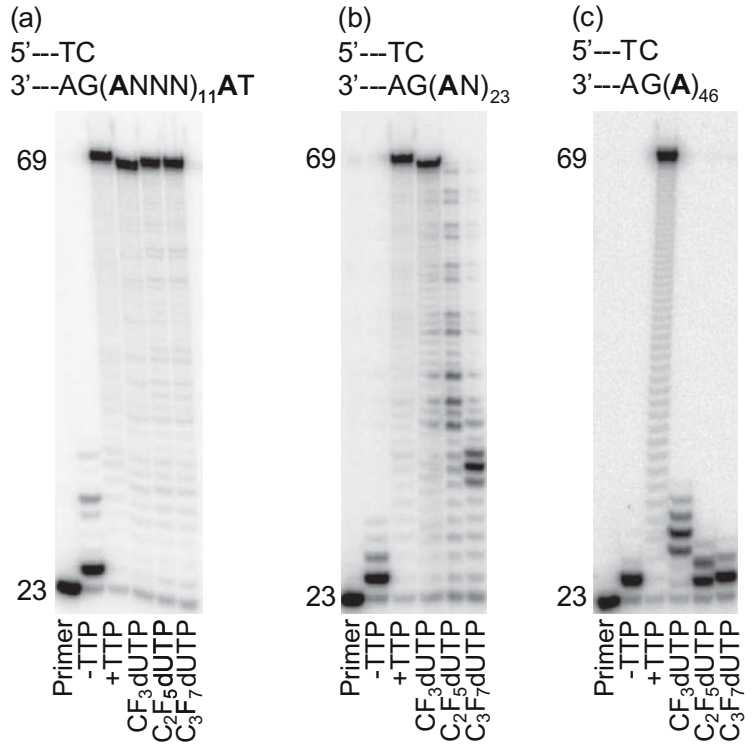

Figure 3. Multiple incorporation of modified nucleotides. Primer template sequences are indicated on the top of every panel. (a-c) Incorporation by $\mathrm{KF}($ exo-) catalysis; Primer: primer only; -TTP: primer extension in the presence of dATP, dGTP and dCTP; +TTP: as - TTP but in the presence of TTP; $C F_{3} d U T P$ : as -TTP but in the presence of $\mathbf{1 a}$; $C_{2} F_{5} d U T P$ : as - TTP but in the presence of $\mathbf{1 b} ; C_{3} F_{7} d U T P$ : as -TTP but in the presence of $\mathbf{1 c}$. incorporates only about 46 adjacent nucleotides under the same conditions (Fig. 4b, middle and right panel). This inhibition of DNA synthesis is in part surprising since it has been shown that bulkier nucleotides are accepted by the same DNA polymerase. ${ }^{2,3}$ However, the nucleotide perfluoroalkyl modification hampers catalysis to a greater extent. Thereby, the pentafluoroethyl and heptafluoro $n$ propyl modified residues exhibit enhanced inhibi tion of DNA synthesis in comparison to the $\mathrm{CF}_{3} \mathrm{dU}$ residue. Pertur bation of DNA polymerase/DNA contacts, for example, $\mathrm{H}$ bonds between amino acid side chains and the nucleobases which are re quired for binding and activity of the enzyme might be the origin of this effect.

\section{Conclusions}

In summary, we report the synthesis of 5 trifluoromethyl , 5 pentafluoroethyl and 5 (heptafluoro $n$ propyl) $2^{\prime}$ deoxyuridine $5^{\prime}$ triphosphates 1a $\mathbf{c}$ and their usage for site specific introduction of perfluorinated residues into DNA in DNA polymerase catalyzed template directed reactions. Since fluorine has properties that are distinct from other polar or non polar modifications the herein de picted approach presents new routes for the generation of highly modified nucleic acids for future DNA biotechnological applica tions like in SELEX. Directed evolution of DNA polymerases might be suited for the improvement of enzymes' proficiencies to process non natural substrates. ${ }^{20}$

\section{Experimental}

\subsection{General}

NMR spectra were recorded on a Bruker AC 250 Cryospec, a Bruker DRX 600 and a Jeol ECX 400 spectrometer. ESI IT mass spectra were recorded on a Bruker Daltonics esquire 3000+. ESI TOF mass spectra were recorded on a Bruker micrOTOFII. All re agents are commercially available and were used without further purification. Solvents were stored over molecular sieves (Fluka) and used directly without further purification.

\subsubsection{5-Trifluoromethyl-2'-deoxyuridine 3a}

To cleave the acetyl protecting groups, compound 2a (445 mg, $1.17 \mathrm{mmol}$ ) was treated with a $7 \mathrm{M}$ ammonia solution of methanol $(4.5 \mathrm{~mL})$ for $19 \mathrm{~h}$ at room temperature (TLC analysis EtOAc/petro leum ether 5/1). The solvent was removed in vacuo and the crude product was purified by silica gel chromatography (eluent: EtOAc/ petroleum ether 5/1) to yield 3a (264 mg, 76\%). TLC (EtOAc/petro leum ether 5/1) $R_{\mathrm{f}} 0.34 .{ }^{1} \mathrm{H}$ NMR $\left(600 \mathrm{MHz} ; \mathrm{MeOH} d_{4}\right) \delta(\mathrm{ppm})$ 2.252 .29 (m, 1H, H2'a), 2.352 .39 (m, 1H, H2'b), 3.75 (dd, 1H, $\left.\mathrm{H}^{\prime} \mathrm{a},{ }^{2} J_{\mathrm{H} 5^{\prime} \mathrm{b}}=12 \mathrm{~Hz},{ }^{3} \mathrm{JH}_{\mathrm{H} 4^{\prime}}=3 \mathrm{~Hz}\right), 3.84\left(\mathrm{dd}, 1 \mathrm{H}, \mathrm{H} 5^{\prime} \mathrm{b},{ }^{2} \mathrm{~J}_{\mathrm{H} 5^{\prime} \mathrm{a}}=12 \mathrm{~Hz}\right.$, $\left.{ }^{3} J_{\mathrm{H} 4^{\prime}}=3 \mathrm{~Hz}\right), 3.97\left(\mathrm{~m}, 1 \mathrm{H}, \mathrm{H} 4^{\prime}\right), 4.41\left(\mathrm{~m}, 1 \mathrm{H}, \mathrm{H} 3^{\prime}\right), 6.24(\mathrm{dd}, 1 \mathrm{H}$, $\left.\mathrm{H} 1^{\prime},{ }^{3} J_{\mathrm{H}^{\prime}}=6 \mathrm{~Hz}\right), 8.79(\mathrm{~s}, 1 \mathrm{H}, \mathrm{H} 6) .{ }^{13} \mathrm{C}$ NMR $\left(151 \mathrm{MHz} ; \mathrm{MeOH} d_{4}\right)$ $\delta(\mathrm{ppm}) 42.15,62.17,71.73,87.58,89.34,105.35$ (q, 1C, C5, $\left.{ }^{2} J_{\mathrm{F}}=33 \mathrm{~Hz}\right), 123.98\left(\mathrm{q}, 1 \mathrm{C}, \mathrm{CF}_{3},{ }^{1} J_{\mathrm{F}}=269 \mathrm{~Hz}\right), 143.82(\mathrm{q}, 1 \mathrm{C}, \mathrm{C} 6$, $\left.{ }^{3} J_{\mathrm{F}}=6 \mathrm{~Hz}\right), 151.37,161.27 .{ }^{19} \mathrm{~F}$ NMR $\left(376 \mathrm{MHz} ; \mathrm{MeOH} d_{4}\right) \delta$ (ppm) $64.4\left(\mathrm{~s}, 3 \mathrm{~F}, \mathrm{CF}_{3}\right)$. ESI IT MS calcd for $(\mathrm{M} \mathrm{H}) 295.1$, found 294.8. ESI TOF MS calcd for (M H) 295.0542, found 295.0536.

\subsubsection{5-Pentafluoroethyl-2'-deoxyuridine $3 b$}

The deacetylation of compound $\mathbf{2 b}(140 \mathrm{mg}, 0.33 \mathrm{mmol})$ was performed in dichloromethane and methanol $(9: 1 ; 10 \mathrm{~mL})$ with toluene 4 sulfonic acid monohydrate $(309 \mathrm{mg}, 1.63 \mathrm{mmol}$ ) for 3 days at room temperature to get full turnover of the reactant (TLC analysis EtOAc/petroleum ether 5/1). The solvent was re moved in vacuo and the crude product was purified by RP MPLC (linear grade from water with $5 \%$ acetonitrile to $100 \%$ acetonitrile) 
(a) $\begin{array}{ll}\text { Primer }(23 \mathrm{nt}): & \text { 5'--TC } \\ \text { Template }(49 \mathrm{nt}): & \text { 3'-AGA AAA AAA AAA AGG TTG CGT GGT CCG T }\end{array}$

(b)
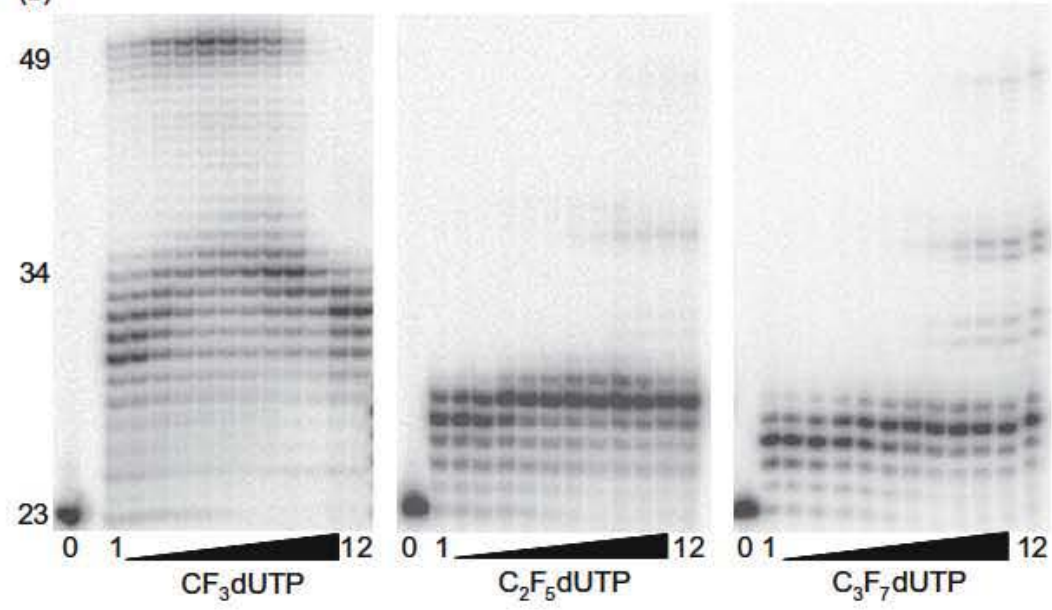

Figure 4. Temperature dependent polymerization of 1a-c by Therminator DNA polymerase; lanes 0: primer only, lanes 1-12: primer extension in the presence of dATP, dGTP, dCTP and 1a, 1b, or 1c, respectively; incubation temperatures: $37.0,37.8,40.1,43.7,47.6,51.5,55.4,59.4,63.3,66.9,69.2$ and $70.0{ }^{\circ} \mathrm{C}$.

to yield 3b (84 mg, 74\%). TLC (dichloromethane/methanol 9:1) $R_{\mathrm{f}}$ 0.30. ${ }^{1} \mathrm{H}$ NMR $\left(600 \mathrm{MHz} ; \mathrm{MeOH} d_{4}\right) \delta(\mathrm{ppm}) 2.232 .29(\mathrm{~m}, 1 \mathrm{H}$, H2'a), 2.372 .41 (m, 1H, H2'b), 3.74 (dd, $1 \mathrm{H}, \mathrm{H}^{\prime} \mathrm{a}^{\prime}{ }^{2} \mathrm{~J}_{\mathrm{H} 5^{\prime} \mathrm{b}}=12 \mathrm{~Hz}$, ${ }^{3} J_{\mathrm{H}^{\prime}}=3 \mathrm{~Hz}$ ), $3.83\left(\mathrm{dd}, 1 \mathrm{H}, \mathrm{H} 5^{\prime} \mathrm{b},{ }^{2} J_{\mathrm{H} 5^{\prime} \mathrm{a}}=12 \mathrm{~Hz},{ }^{3} \mathrm{~J}_{\mathrm{H} 4^{\prime}}=3 \mathrm{~Hz}\right.$ ), 3.98 $\left(\mathrm{m}, 1 \mathrm{H}, \mathrm{H} 4^{\prime}\right), 4.41\left(\mathrm{~m}, 1 \mathrm{H}, \mathrm{H} 3^{\prime}\right), 6.24\left(\mathrm{dd}, 1 \mathrm{H}, \mathrm{H}^{\prime},{ }^{3} \mathrm{~J}_{\mathrm{H}}=6 \mathrm{~Hz}\right)$, $8.80(\mathrm{~s}, 1 \mathrm{H}, \mathrm{H} 6) .{ }^{13} \mathrm{C}$ NMR (151 MHz; $\left.\mathrm{MeOH} d_{4}\right) \delta(\mathrm{ppm}) 42.30$, $62.16,71.80,87.79,89.45,103.05\left(t, 1 C, C 5,{ }^{2} J_{F}=24 \mathrm{~Hz}\right), 113.71$ (tq, $1 \mathrm{C}, \mathrm{CF}_{2}, J_{\mathrm{F}}=254 \mathrm{~Hz},{ }^{2} J_{\mathrm{F}}=40 \mathrm{~Hz}$ ), 120.49 (tq, $1 \mathrm{C}, \mathrm{CF}_{3}$, $\left.{ }^{1} J_{\mathrm{F}}=286 \mathrm{~Hz},{ }^{2} J_{\mathrm{F}}=40 \mathrm{~Hz}\right), 145.85\left(\mathrm{t}, 1 \mathrm{C}, \mathrm{C} 6,{ }^{3} J_{\mathrm{F}}=10 \mathrm{~Hz}\right), 151.29$, 160.97. ${ }^{19} \mathrm{~F}$ NMR $\left(376 \mathrm{MHz} ; \mathrm{MeOH} d_{4}\right) \delta(\mathrm{ppm}) 114.8(\mathrm{~s}, 1 \mathrm{~F}$, $\left.\mathrm{CF}_{2} \mathrm{a}\right), \quad 114.8\left(\mathrm{~s}, 1 \mathrm{~F}, \mathrm{CF}_{2} \mathrm{~b}\right), \quad 86.0\left(\mathrm{~s}, 3 \mathrm{~F}, \mathrm{CF}_{3}\right)$. ESI IT MS calcd for (M H) 345.1, found: 344.8. ESI TOF MS calcd for (M H) 345.0510 , found 345.0609 .

\subsubsection{5-(Heptafluoro-n-propyl)-2'-deoxyuridine $3 c$}

The deacetylation of compound $2 c(161 \mathrm{mg}, 0.33 \mathrm{mmol})$ was performed in dichloromethane and methanol $(9: 1 ; 10 \mathrm{~mL})$ with tol uene 4 sulfonic acid monohydrate ( $319 \mathrm{mg}, 1.68 \mathrm{mmol}$ ) for 3 days at room temperature (TLC analysis EtOAc/petroleum ether 5/1). The solvent was removed in vacuo and the crude product was purified by RP MPLC (linear grade from water with $5 \%$ acetonitrile to $100 \%$ acetonitrile) to yield $3 \mathrm{c}(87 \mathrm{mg}, 66 \%)$. TLC (dichloromethane/meth anol 9:1) $R_{\mathrm{f}} 0.36 .{ }^{1} \mathrm{H}$ NMR ( $600 \mathrm{MHz}$; $\left.\mathrm{MeOH} d_{4}\right) \delta(\mathrm{ppm}) 2.222 .28$ (m, 1H, H2'a), 2.352 .43 (m, 1H, H2'b), 3.74 (dd, $1 \mathrm{H}, \mathrm{H}^{\prime} \mathrm{a}$, ${ }^{2} J_{\mathrm{H}^{\prime} \mathrm{b}}=12 \mathrm{~Hz},{ }^{3} J_{\mathrm{H} 4^{\prime}}=2 \mathrm{~Hz}$ ), 3.82 (dd, $1 \mathrm{H}, \mathrm{H}^{\prime} \mathrm{b},{ }^{2} \mathrm{~J}_{\mathrm{H} 5^{\prime} \mathrm{a}}=12 \mathrm{~Hz}$, $\left.{ }^{3} \mathrm{H}_{\mathrm{H}^{\prime}}=3 \mathrm{~Hz}\right), 3.98\left(\mathrm{~m}, 1 \mathrm{H}, \mathrm{H} 4^{\prime}\right), 4.41\left(\mathrm{~m}, 1 \mathrm{H}, \mathrm{H} 3^{\prime}\right), 6.25(\mathrm{dd}, 1 \mathrm{H}$, $\left.\mathrm{H}^{\prime},{ }^{3} \mathrm{H}_{\mathrm{H} \prime^{\prime}}=6 \mathrm{~Hz}\right), 8.81(\mathrm{~s}, 1 \mathrm{H}, \mathrm{H} 6) .{ }^{13} \mathrm{C} \mathrm{NMR}\left(151 \mathrm{MHz} ; \mathrm{MeOH} d_{4}\right) \delta$ (ppm) 42.38, 62.17, 71.85, 87.79, 89.50, 103.21 (t, 1C, C5, $\left.{ }^{2} J_{\mathrm{F}}=24 \mathrm{~Hz}\right), 110.36\left(\mathrm{~m}, 1 \mathrm{C}, \mathrm{CF}_{2} \beta\right), 115.69\left(\mathrm{tq}, 1 \mathrm{C}, \mathrm{CF}_{2} \alpha,{ }^{1} J_{\mathrm{F}}=256 \mathrm{~Hz}\right.$, $\left.{ }^{2} J_{\mathrm{F}}=33 \mathrm{~Hz}\right), 119.49\left(\mathrm{tq}, 1 \mathrm{C}, \mathrm{CF}_{3},{ }^{1} J_{\mathrm{F}}=287 \mathrm{~Hz},{ }^{2} J_{\mathrm{F}}=34 \mathrm{~Hz}\right), 146.19(\mathrm{t}$, $\left.1 \mathrm{C}, \mathrm{C} 6,{ }_{\mathrm{F}}^{3}=10 \mathrm{~Hz}\right), 151.26,160.95 .{ }^{19} \mathrm{~F}$ NMR $\left(376 \mathrm{MHz} ; \mathrm{MeOH} d_{4}\right)$ $\delta(\mathrm{ppm}) \quad 127.5\left(\mathrm{~s}, 2 \mathrm{~F}, \mathrm{CF}_{2} \beta\right), \quad 111.5\left(\mathrm{~m}, 1 \mathrm{~F}, \mathrm{CF}_{2} \alpha\right), \quad 82.4(\mathrm{t}, 3 \mathrm{~F}$, $\mathrm{CF}_{3},{ }^{4} \mathrm{~J}_{\mathrm{F} \alpha}=10 \mathrm{~Hz}$ ). ESI IT MS calcd for $(\mathrm{M} \mathrm{H})$ 395.1, found 394.8 . ESI TOF MS calcd for (M H) 395.0478, found 395.0595.

\subsubsection{5-Trifluoromethyl-2'-deoxyuridine-5'-triphosphate 1 a}

The nucleoside $3 \mathrm{a}(67 \mathrm{mg}, 0.23 \mathrm{mmol})$ and 1,8 bis (dimethyl amino)naphthalene ( $72 \mathrm{mg}, 0.34 \mathrm{mmol}$ ) were dried in the dark in vacuo overnight. Then the mixture was dissolved under argon in trimethyl phosphate $(1.8 \mathrm{~mL})$ and $\mathrm{POC}_{3}(55 \mu \mathrm{L}, 0.60 \mathrm{mmol})$ was added dropwise at $0^{\circ} \mathrm{C}$. After full turnover of the reactant (TLC analysis 2 propanol/ $/ \mathrm{NH}_{3} / \mathrm{H}_{2} \mathrm{O} 3 / 1 / 1$ ) a $0.5 \mathrm{M}$ bis tri $n$ butylammo nium pyrophosphate solution of DMF ( $2.25 \mathrm{~mL}, 1.13 \mathrm{mmol})$ and $n$ tributylamine ( $540 \mu \mathrm{L}, 2.27 \mathrm{mmol}$ ) were added simultaneously. After stirring for additional $20 \mathrm{~min} 1 \mathrm{M} \mathrm{TEAB}$ buffer $\left(\mathrm{Et}_{3} \mathrm{NH}\left(\mathrm{HCO}_{3}\right)\right.$, $\mathrm{pH} 7.5)$ was added $(10 \mathrm{~mL})$. The aqueous layer was washed with EtOAc $(2 \times 10 \mathrm{~mL})$ and the solvent was removed in vacuo. The res idue was resolved in $0.1 \mathrm{M}$ TEAB buffer $(3 \mathrm{~mL})$ and purified by sephadex ion exchange chromatography (eluent: linear grade from $0.1 \mathrm{M}$ to $1 \mathrm{M}$ TEAB buffer). The salts were removed by RP MPLC (eluent: grade from $50 \mathrm{mM}$ TEAA buffer $\left(\mathrm{Et}_{3} \mathrm{NH}(\mathrm{OAc}), \mathrm{pH}\right.$ 7.0) with $5 \%$ acetonitrile to $100 \%$ acetonitrile) to yield $1 \mathrm{a}(18 \mathrm{mg}, 8 \%$, trieth ylammonium salt of the triphosphate). ${ }^{1} \mathrm{H}$ NMR ( $400 \mathrm{MHz} ; \mathrm{MeOH}$ $\left.d_{4}\right) \delta(\mathrm{ppm}) 1.30\left(\mathrm{t}, \mathrm{Et}_{3} \mathrm{~N}, \mathrm{Me}\right), 2.32\left(\mathrm{~m}, 2 \mathrm{H}, \mathrm{H} 2^{\prime}\right), 3.17\left(\mathrm{q}, \mathrm{Et}_{3} \mathrm{~N}, \mathrm{CH}_{2}\right.$ ), $4.094 .22\left(\mathrm{~m}, 2 \mathrm{H}, \mathrm{H} 5^{\prime}\right), 4.31\left(\mathrm{~m}, 1 \mathrm{H}, \mathrm{H} 4^{\prime}\right), 4.59\left(\mathrm{~m}, 1 \mathrm{H}, \mathrm{H} 3^{\prime}\right), 6.19$ (dd, $1 \mathrm{H}, \mathrm{H}^{\prime},{ }^{3} J_{\mathrm{H} 2^{\prime}}=7 \mathrm{~Hz}$ ), $8.29(\mathrm{~s}, 1 \mathrm{H}, \mathrm{H} 6) .{ }^{31} \mathrm{P}$ NMR $(162 \mathrm{MHz}$; $\left.\mathrm{MeOH} d_{4}\right) \delta(\mathrm{ppm}) 22.94\left(\mathrm{dd}, 1 \mathrm{P}, \mathrm{P}_{\beta},{ }^{2} \mathrm{~J}_{\mathrm{P}}=21 \mathrm{~Hz}\right), 10.66(\mathrm{~d}, 1 \mathrm{P}$, $\left.\mathrm{P}_{\alpha},{ }^{2} J_{\mathrm{P} \beta}=21 \mathrm{~Hz}\right), \quad 9.56\left(\mathrm{~d}, 1 \mathrm{P}, \quad \mathrm{P}_{\gamma},{ }^{2} J_{\mathrm{P} \beta}=21 \mathrm{~Hz}\right) .{ }^{19} \mathrm{~F} \quad \mathrm{NMR}$ $\left(376 \mathrm{MHz} ; \mathrm{MeOH} d_{4}\right) \delta(\mathrm{ppm}) 64.7\left(\mathrm{~s}, 3 \mathrm{~F}, \mathrm{CF}_{3}\right)$. ESI IT MS calcd for $(\mathrm{M} \mathrm{H})$ 534.9, found 534.6. ESI TOF MS calcd for (M H) 534.9537, found 534.9651.

\subsubsection{5-Pentafluoroethyl-2'-deoxyuridine-5'-triphosphate $1 \mathrm{~b}$}

The nucleoside $3 \mathbf{b}(32 \mathrm{mg}, 0.09 \mathrm{mmol})$ and 1,8 bis(dimethyl amino)naphthalene ( $30 \mathrm{mg}, 0.14 \mathrm{mmol}$ ) were dried in the dark in vacuo overnight. Then the mixture was dissolved under argon in trimethyl phosphate $(1 \mathrm{~mL})$ and $\mathrm{POCl}_{3}(20 \mu \mathrm{L}, 0.22 \mathrm{mmol})$ was added dropwise at $0{ }^{\circ} \mathrm{C}$. After full turnover of the reactant (TLC analysis 2 propanol/ $\mathrm{NH}_{3} / \mathrm{H}_{2} \mathrm{O} 3 / 1 / 1$ ) a $0.5 \mathrm{M}$ bis tri $n$ butylammo nium pyrophosphate solution of DMF $(0.92 \mathrm{~mL}, 0.46 \mathrm{mmol})$ and $n$ tributylamine $(220 \mu \mathrm{L}, 0.92 \mathrm{mmol})$ were added simultaneously. After stirring for additional $20 \mathrm{~min} 1 \mathrm{M} \mathrm{TEAB}$ buffer $\left(\mathrm{Et}_{3} \mathrm{NH}\left(\mathrm{HCO}_{3}\right)\right.$, $\mathrm{pH} 7.5)$ was added $(10 \mathrm{~mL})$. The aqueous layer was washed with EtOAc $(2 \times 10 \mathrm{~mL})$ and the solvent was removed in vacuo. The res idue was resolved in $0.1 \mathrm{M}$ TEAB buffer $(3 \mathrm{~mL})$ and purified by sephadex ion exchange chromatography (linear gradient from $0.1 \mathrm{M}$ to $1 \mathrm{M}$ TEAB buffer). The salts were removed by RP MPLC (gradient from $50 \mathrm{mM}$ TEAA buffer $\left(\mathrm{Et}_{3} \mathrm{NH}(\mathrm{OAC}), \mathrm{pH} 7.0\right.$ ) with $5 \%$ acetonitrile to $100 \%$ acetonitrile) to yield $1 \mathrm{~b}(9 \mathrm{mg}, 10 \%$, triethyl ammonium salt of the triphosphate). ${ }^{1} \mathrm{H}$ NMR ( $400 \mathrm{MHz} ; \mathrm{MeOH}$ 
$\left.d_{4}\right) \delta(\mathrm{ppm}) 1.24\left(\mathrm{t}, \mathrm{Et}_{3} \mathrm{~N}, \mathrm{Me}\right), 2.44\left(\mathrm{~m}, 2 \mathrm{H}, \mathrm{H} 2^{\prime}\right), 3.26\left(\mathrm{q}, \mathrm{Et}_{3} \mathrm{~N}, \mathrm{CH}_{2}\right)$, $4.114 .32\left(\mathrm{~m}, 3 \mathrm{H}, \mathrm{H} 4^{\prime}, \mathrm{H} 5^{\prime}\right), 4.66\left(\mathrm{~m}, 1 \mathrm{H}, \mathrm{H} 3^{\prime}\right), 6.24\left(\mathrm{dd}, 1 \mathrm{H}, \mathrm{H} 1^{\prime}\right.$, $\left.{ }^{3} J_{\mathrm{H}^{\prime}}=7 \mathrm{~Hz}\right), 8.28(\mathrm{~s}, 1 \mathrm{H}, \mathrm{H} 6) .{ }^{31} \mathrm{P}$ NMR $\left(162 \mathrm{MHz} ; \mathrm{MeOH} d_{4}\right) \delta$ $(\mathrm{ppm}) 22.43\left(\mathrm{~m}, 1 \mathrm{P}, \mathrm{P}_{\beta}\right), \quad 11.04\left(\mathrm{~d}, 1 \mathrm{P}, \mathrm{P}_{\alpha},{ }^{2} J_{\mathrm{P} \beta}=19 \mathrm{~Hz}\right), \quad 9.56$ (d, $\left.1 \mathrm{P}, \mathrm{P}_{\gamma},{ }^{2} J_{\mathrm{P} \beta}=17 \mathrm{~Hz}\right) .{ }^{19} \mathrm{~F} \mathrm{NMR}\left(376 \mathrm{MHz} ; \mathrm{MeOH} d_{4}\right) \delta(\mathrm{ppm})$ $114.6\left(\mathrm{~s}, 2 \mathrm{~F}, \mathrm{CF}_{2}\right), \quad 85.5\left(\mathrm{~s}, 3 \mathrm{~F}, \mathrm{CF}_{3}\right)$. ESI IT MS calcd for $(\mathrm{M} \mathrm{H})$ 584.9, found 584.5. ESI TOF MS calcd for (M H) 584.9505, found 584.9688

\subsubsection{5-(Heptafluoro-n-propyl)-2'-deoxyuridine-5'- triphosphate 1c}

The nucleoside $\mathbf{3 c}(31 \mathrm{mg}, 0.08 \mathrm{mmol})$ and 1,8 bis (dimethyl amino)naphthalene ( $25 \mathrm{mg}, 0.12 \mathrm{mmol}$ ) were dried in the dark in vacuo overnight. Then the mixture was dissolved under argon in trimethyl phosphate $(1 \mathrm{~mL})$ and $\mathrm{POCl}_{3}(29 \mu \mathrm{L}, 0.32 \mathrm{mmol})$ was added dropwise at $0{ }^{\circ} \mathrm{C}$. After full turnover of the reactant (TLC analysis 2 propanol/ $\left./ \mathrm{NH}_{3} / \mathrm{H}_{2} \mathrm{O} 3 / 1 / 1\right)$ a $0.5 \mathrm{M}$ bis tri $n$ butylammo nium pyrophosphate solution of DMF $(0.78 \mathrm{~mL}, 0.39 \mathrm{mmol})$ and $n$ tributylamine $(190 \mu \mathrm{L}, 0.80 \mathrm{mmol})$ were added simultaneously. After stirring for additional 20 min $1 \mathrm{M} \mathrm{TEAB}$ buffer $\left(\mathrm{Et}_{3} \mathrm{NH}\left(\mathrm{HCO}_{3}\right)\right.$, $\mathrm{pH} 7.5$ ) was added $(10 \mathrm{~mL})$. The aqueous layer was washed with EtOAc $(2 \times 10 \mathrm{~mL})$ and the solvent was removed in vacuo. The res idue was resolved in $0.1 \mathrm{M}$ TEAB buffer $(3 \mathrm{~mL})$ and purified by sephadex ion exchange chromatography (eluent: linear grade from $0.1 \mathrm{M}$ to $1 \mathrm{M}$ TEAB buffer). The salts were removed by RP MPLC (eluent: grade from $50 \mathrm{mM}$ TEAA buffer $\left(\mathrm{Et}_{3} \mathrm{NH}(\mathrm{OAc}), \mathrm{pH} 7.0\right)$ with $5 \%$ acetonitrile to $100 \%$ acetonitrile) to yield $1 \mathrm{c}(13 \mathrm{mg}, 16 \%$, trieth ylammonium salt of the triphosphate). ${ }^{1} \mathrm{H}$ NMR $\left(400 \mathrm{MHz} ; \mathrm{d}_{4}\right.$ $\mathrm{MeOH}) \delta(\mathrm{ppm}) 1.30\left(\mathrm{~m}, \mathrm{Et}_{3} \mathrm{~N}, \mathrm{Me}\right), 2.252 .43\left(\mathrm{~m}, 2 \mathrm{H}, \mathrm{H} 2^{\prime}\right), 3.17$ $\left(\mathrm{m}, \mathrm{Et}_{3} \mathrm{~N}, \mathrm{CH}_{2}\right), 4.094 .31\left(\mathrm{~m}, 3 \mathrm{H}, \mathrm{H}^{\prime}, \mathrm{H}^{\prime}\right), 4.58\left(\mathrm{~m}, 1 \mathrm{H}, \mathrm{H}^{\prime}\right)$, $6.15\left(\mathrm{dd}, 1 \mathrm{H}, \mathrm{H} 1^{\prime},{ }^{3} \mathrm{~J}_{\mathrm{H} 2^{\prime}}=7 \mathrm{~Hz}\right), 8.15(\mathrm{~s}, 1 \mathrm{H}, \mathrm{H} 6) .{ }^{31} \mathrm{P}$ NMR $\left(162 \mathrm{MHz} ; \mathrm{MeOH} d_{4}\right) \delta(\mathrm{ppm}) 22.90\left(\mathrm{dd}, 1 \mathrm{P}, \mathrm{P}_{\beta},{ }^{2} J_{\mathrm{P}}=21 \mathrm{~Hz}\right)$, $10.60\left(\mathrm{~d}, 1 \mathrm{P}, \mathrm{P}_{\alpha},{ }^{2} J_{\mathrm{P} \beta}=21 \mathrm{~Hz}\right), \quad 9.56\left(\mathrm{~d}, 1 \mathrm{P}, \mathrm{P}_{\gamma},{ }^{2} J_{\mathrm{P} \beta}=21 \mathrm{~Hz}\right) .{ }^{19} \mathrm{~F}$ $\operatorname{NMR}\left(376 \mathrm{MHz} ; \mathrm{MeOH} d_{4}\right) \delta(\mathrm{ppm}) \quad 127.1\left(\mathrm{~m}, 2 \mathrm{~F}, \mathrm{CF}_{2 \beta}\right), \quad 111.5$ (q, 2F, $\left.\mathrm{CF}_{2} \alpha,{ }^{4} J_{\mathrm{F}}=10 \mathrm{~Hz}\right), \quad 82.2\left(\mathrm{t}, 3 \mathrm{~F}, \mathrm{CF}_{3},{ }^{4} J_{\mathrm{F}}=10 \mathrm{~Hz}\right)$. ESI IT MS calcd for $(\mathrm{M} \mathrm{H})$ 634.9, found 634.5. ESI TOF MS calcd for $(\mathrm{M} \mathrm{H})$ 634.9473 , found 634.9729

\subsubsection{Materials for DNA polymerase experiments}

dNTPs were purchased from Roche.

4.1.7.1. Primers and templates. Figures 1,3 and 4: Tem plates were obtained from Purimex ( $2 \times$ HPLC purified). The $23 \mathrm{nt}$ primer strand was synthesized on an Applied Biosystems 392 DNA synthesizer and afterwards purified by preparative PAGE. Fig ure 2: Used primer and templates were synthesized on the DNA synthesizer and afterwards purified by HPLC and preparative PAGE.

4.1.7.2. Enzymes. The Klenow fragment of E. coli DNA poly merase I ( $\mathrm{KF}($ exo $)$ ) was generated and purified as described. ${ }^{21}$ The Klenow fragment of Thermus aquaticus DNA polymerase I (KlenTaq) was generated and purified as described. ${ }^{20 f}$ The Thermi nator DNA polymerase (A485L mutant of Thermococcus species $9^{\circ} \mathrm{N}$ DNA polymerase) was purchased from New England Biolabs.

4.1.7.3. Buffers. $\quad 10 x$ reaction buffer $\mathrm{KF}($ exo $): 500 \mathrm{mM}$ Tris $\mathrm{HCl}, 100 \mathrm{mM} \mathrm{MgCl}_{2}, 10 \mathrm{mM}$ DTT, 0,5\% Triton X 100, pH 7.3. $10 \times$ reaction buffer KlenTaq: $500 \mathrm{mM}$ Tris $\mathrm{HCl}, 160 \mathrm{mM}\left(\mathrm{NH}_{4}\right)_{2} \mathrm{SO}_{4}$, $25 \mathrm{mM} \mathrm{MgCl}_{2}, 1 \%$ Tween 20, pH 9.2. $10 \times$ reaction buffer Thermina tor: $200 \mathrm{mM}$ Tris $\mathrm{HCl}, 20 \mathrm{mM} \mathrm{MgSO}{ }_{4}, 100 \mathrm{mM}\left(\mathrm{NH}_{4}\right)_{2} \mathrm{SO}_{4}, 100 \mathrm{mM}$ $\mathrm{KCl}, 1 \%$ Triton X 100, pH 8.8 .

\subsubsection{Primer extension assays (Figs. 1,3 and 4 )}

The $23 \mathrm{nt}$ long primer was $5^{\prime}{ }^{32} \mathrm{P}$ labelled using $\left[\gamma^{32} \mathrm{P}\right]$ ATP according to standard techniques. The reaction mixture $(20 \mu \mathrm{L})$ contained DNA polymerase, $200 \mathrm{nM}$ template, $150 \mathrm{nM}$ radioactive labelled primer ( $5^{\prime} \mathrm{d}\left(\mathrm{GAC}\right.$ CCA CTC CAT CGA GAT TTC TC) $\left.3^{\prime}\right)$ and $200 \mu \mathrm{M}$ dNTPs in the according $1 \times$ reaction buffer. Used DNA poly merase concentrations were (i) for reactions depicted in Figure 1b: 30 nM DNA polymerase $\mathrm{KF}$ (exo ), (ii) for reactions depicted in Fig ure 1c: 30 nM DNA polymerase KlenTaq, (iii) for reactions depicted in Figure 3: $10 \mathrm{nM}$ DNA polymerase $\mathrm{KF}$ (exo ) and (iv) for reactions depicted in Figure 4: $0.05 \mathrm{U} / \mu \mathrm{L}$ Therminator DNA polymerase. The reactions were incubated (i) for reactions depicted in Figure $1 \mathrm{~b}$ and c: for 20 min at $37^{\circ} \mathrm{C}(\mathrm{KF}($ exo $))$ and $72^{\circ} \mathrm{C}$ (KlenTaq), (ii) for reac tions depicted in Figure 3: for 60 min at $37{ }^{\circ} \mathrm{C}$ and (iii) for reactions depicted in Figure 4: for $60 \mathrm{~min}$ at 37.0, 37.8, 40.1, 43.7, 47.6, 51.5, $55.4,59.4,63.3,66.9,69.2$ and $70.0^{\circ} \mathrm{C}$, respectively (lanes 1 12) in a thermocycler and were stopped by addition of $40 \mu \mathrm{L}$ stop solu tion (80\% [v/v] formamide, $20 \mathrm{mM}$ EDTA, 0.025\% [w/v] bromophe nol blue, $0.025 \%[\mathrm{w} / \mathrm{v}]$ xylene cyanol). After denaturing at $95^{\circ} \mathrm{C}$ for 5 min the reaction mixtures were separated using a $12 \%$ denatur ing PAGE gel. Visualization was performed using phosphorimaging.

The used templates were (i) for reactions depicted in Figure $1 \mathrm{~b}$ and c: $5^{\prime} \mathrm{d}$ (GCG CTG GCA CGG GAG AAA TCT CGA TGG AGT GGG TC) (35 nt), (ii) for reactions depicted in Figure 3a: $5^{\prime}$ d(TAG GGA TCT ATT TAC TTA CCG ATT CAT TTA CGC AGT CAG GCA TTC AGA GAA ATC TCG ATG GAG TGG GTC) (69 nt), (iii) for reactions de picted in Figure $3 \mathrm{~b}: 5^{\prime} \mathrm{d}(\mathrm{TAG}$ ACA TAG ACA TAG ACA TAG ACA TAG ACA TAC AGA CAG ACA TAC AGA GAA ATC TCG ATG GAG TGG GTC) (69 nt), (iv) for reactions depicted in Figure 3c: $5^{\prime}$ d(AAA AAA AAA AAA AAA AAA AAA AAA AAA AAA AAA AAA AAA AAA AAA AGA GAA ATC TCG ATG GAG TGG GTC) (69 nt) and (v) for reactions depicted in Figure 4: $5^{\prime}$ d(TGC CTG GTG CGT TGG AAA AAA AAA AAG AGA AAT CTC GAT GGA GTG GGT C) (49 nt).

\subsubsection{Single nucleotide incorporation assays (Fig. 2)}

The $24 \mathrm{nt}$ long primer was $5^{\prime}{ }^{32} \mathrm{P}$ labelled using $\left[\gamma^{32} \mathrm{P}\right]$ ATP according to standard techniques. The reaction mixture $(20 \mu \mathrm{L})$ contained $2 \mathrm{nM}$ DNA polymerase $\mathrm{KF}($ exo $), 60 \mathrm{nM}$ template (5' d(GTG CGT CTG TCA/G/C/T TGT CTG TCA GAA ATT TCG CAC CAC), $40 \mathrm{nM}$ radioactive labelled primer ( $5^{\prime} \mathrm{d}$ (GTG GTG CGA AAT TTC TGA CAG ACA) $3^{\prime}$ ) and 1, 10, $100 \mu \mathrm{M}$ dNTPs (matched case) or $10,50,200 \mu \mathrm{M}$ dNTPs (mismatched cases) in $1 \mathrm{x}$ reaction buffer $\mathrm{KF}($ exo ). The reactions were incubated for $5 \mathrm{~min}$ (matched case) or $30 \mathrm{~min}$ (mismatched cases) at $37^{\circ} \mathrm{C}$ in a thermocycler and were stopped by addition of $40 \mu \mathrm{L}$ stop solution ( $80 \%$ [v/v] formamide, $20 \mathrm{mM}$ EDTA, 0.025\% [w/v] bromophenol blue, 0.025\% [w/v] xylene cyanol). After denaturing at $95^{\circ} \mathrm{C}$ for $5 \mathrm{~min}$ the reaction mixtures were separated using a $12 \%$ denaturing PAGE gel. Visualization was performed using phosphorimaging.

\section{Acknowledgements}

We thank M. Liebmann for her contributions to this work and Konstanz Research School Chemical Biology for financial support.

\section{References and notes}

1. (a) Seeman, N. C. Nature 2003, 421, 427; (b) Feldkamp, U; Niemeyer, C. M. Angew. Chem., Int. Ed. 2006, 45, 1856; (c) Lin, C. X.; Liu, Y.; Rinker, S.; Yan, H. ChemPhysChem 2006, 7, 1641; (d) Deng, Z. X.; Lee, S. H.; Mao, C. D. Nanosci. Nanotechnol. 2005, 5, 1954.

2. (a) Weisbrod, S. H.; Marx, A. Chem. Commun. 2008, 5675; (b) Hocek, M.; Fojta, M. Org. Biomol. Chem. 2008, 6, 2233.

3. (a) Sakthivel, K.; Barbas, C. F., III Angew. Chem., Int. Ed. 1998, 37, 2872; (b) Capek, P.; Cahova, H.; Pohl, R.; Hocek, M.; Gloeckner, C.; Marx, A. Chem. Eur. J. 2007, 13, 6196; (c) Cahova, H.; Havran, L.; Brazdilova, P.; Pivonkova, H.; Pohl, R.; Fojta, M.; Hocek, M. Angew. Chem., Int. Ed. 2008, 47, 2059; (d) Jaeger, S.; Rasched, G.; Kornreich-Leshem, H.; Engeser, M.; Thum, O.; Famulok, M. J. Am. Chem. Soc. 2005, 127, 15071; (e) Jaeger, S.; Famulok, M. Angew. Chem., Int. Ed. 2004, 43, 3337; (f) Thum, O.; Jaeger, S.; Famulok, M. Angew. Chem., Int. Ed. 2001, 40, 3990; (g) Rasched, G.; Ackermann, D.; Schmidt, T. L.; Broekmann, P.; Heckel, A.; Famulok, M. Angew. Chem., Int. Ed. 2008, 47, 967. 
4. (a) Vrabel, M.; Horakova, P.; Pivonkova, H.; Kalachova, L.; Cernocka, H.; Cahova H.; Pohl, R.; Sebest, P.; Havran, L.; Hocek, M.; Fojta, M. Chem. Eur. J. 2009, 15 1144; (b) Weizman, H.; Tor, Y. J. Am. Chem. Soc. 2002, 124, 1568.

5. (a) Gramlich, P. M. E.; Wirges, C. T.; Gierlich, J.; Carell, T. Org. Lett. 2008, 10, 249 (b) Salic, A.; Mitchison, T. J. Proc. Natl. Acad. Sci. U.S.A. 2008, 105, 2415; (c) Weisbrod, S. H.; Marx, A. Chem. Commun. 2007, 1828; (d) Baccaro, A. Weisbrod, S. H.; Marx, A. Synthesis 2007, 1949.

6. Keller, S.; Wang, J.; Chandra, M.; Berger, R.; Marx, A. J. Am. Chem. Soc. 2008, 130 13188.

7. Obeid, S.; Yulikov, M.; Jeschke, G.; Marx, A. Angew. Chem., Int. Ed. 2008, 47 6782.

8. Famulok, M.; Hartig, J. S.; Mayer, G. Chem. Rev. 2007, 107, 3715.

9. Recent examples: (a) Hollenstein, M.; Hipolito, C.; Lam, C.; Dietrich, D.; Perrin D. M. Angew. Chem., Int. Ed. 2008, 47, 4346; (b) Hollenstein, M.; Hipolito, C. J.; Lam, C. H.; Perrin, D. M. Nucleic Acids Res. 2009, 37, 1638.

10. (a) Purser S. Moore, P. R. Swallow, S. Gouverneur V. Chem Soc. Rev. 2008, 37 320; (b) Müller, K.; Faeh, C.; Diederich, F. Science 2007, 317, 1881; (c) Pongdee, R.; Liu, H. Bioorg. Chem. 2004, 32, 393.

11. O'Hagan, D. Chem. Soc. Rev. 2008, 37, 308.

12. (a) Kreutz, C.; Micura, R. In Modified Nucleosides; Herdewijn, P., Ed.; Springer: Berlin, 2008; p 3. Chapter 1; (b) Graber, D. Moroder, H. Micura, R. J. Am Chem. Soc. 2008, 130, 17230; (c) Kreutz, C.; Kählig, H.; Konrat, R.; Micura, R. J. Am. Chem. Soc. 2005, 127, 11558; (d) Barhate, N. B.; Barhate, R. N.; Cekan, P.; Drobny, G.; Sigurdsson, S. T. Org. Lett. 2008, 10, 2745
13. Gmeiner, W. H.; Pon, R. T.; Lown, J. W. J. Org. Chem. 1991, 56, 3602.

14. Markley, J. C.; Chirakul, P.; Sologub, D.; Sigurdsson, S. T. Bioorg. Med. Chem. Lett. 2001, 11, 2453

15. (a) Satake, H.; Takeda, S.; Wataya, Y. Nucleic Acids Symp. Ser. 1991, 25, 37; (b) Satake, H.; Takeda, S.; Matsumura, A.; Sasaki, M.; Sugimoto, N.; Wataya, Y. Nucleic. Acids Symp. Ser. 1992, 27, 189.

16. Tanabe, Y.; Matsuo, N.; Ohno, N. J. Org. Chem. 1988, 53, 4582

17. (a) Takatori, S.; Matsuda, A.; Yamashita, J.-I.; Hayatsu, H.; Wataya, Y. Nucleosides, Nucleotides Nucleic Acids 1994, 13, 2105; (b) Wataya, Y.; Sonobe Y.; Maeda, M.; Yamaizumi, Z.; Aida, M.; Santi, D. V. J. Chem. Soc., Perkin Trans. 1 1987, 2141; (c) Santi, D. V.; Sakai, T. T. Biochemistry 1971, 10, 3598.

18. (a) Yoshikawa, M.; Kato, T.; Takenishi, T. Bull. Chem. Soc. Jpn. 1969, 42, 3505; (b) Kovács, T.; Ötvös, L. Tetrahedron Lett. 1988, 29, 4525.

19. Clark, J. M. Nucleic Acids Res. 1988, 16, 9677.

20. (a) Ghadessy, F. J.; Ramsay, N.; Boudsocq, F.; Loakes, D.; Brown, A.; Iwai, S.; Vaisman, A.; Woodgate, R.; Holliger, P. Nat. Biotechnol. 2004, 22, 755; (b) Leconte, A. M.; Chen, L.; Romesberg, F. E. J. Am. Chem. Soc. 2005, 127, 12470; (c) Vichier-Guerre, S.; Ferris, S.; Auberger, N.; Mahiddine, K.; Jestin, J.-L. Angew. Chem., Int. Ed. 2006, 45, 6133; (d) Xia, G.; Chen, L.; Sera, T.; Fa, M.; Schultz, P. G.; Romesberg, F. E. Proc. Natl. Acad. Sci. U.S.A. 2002, 99, 6597; (e) Sauter, K. B. M.; Marx, A. Angew. Chem., Int. Ed. 2006, 45, 7633; (f) Gloeckner, C.; Sauter, K. B. M. Marx, A. Angew. Chem., Int. Ed. 2007, 46, 3115.

21. Summerer, D.; Marx, A. Angew. Chem., Int. Ed. 2002, 41, 3620. 